\title{
Hydroponic Screening for Iron Deficiency Tolerance in Evergreen Azaleas
}

\author{
Sonia DEMASI ${ }^{1}$, Matteo CASER $^{1}$, Nobuo KOBAYASHI ${ }^{2}$, \\ Yuji KURASHIGE 3 , Valentina SCARIOT ${ }^{1 *}$ \\ ${ }^{1}$ University of Torino, Department of Agricultural Forest and Food Sciences, Largo P. Braccini 2, 10095, Grugliasco, Torino, \\ Italy;sonia.demasi@unito.it;matteo.caser@unito.it;valentina.scariot@unito.it('correspondingauthor) \\ 2Shimane University, Faculty of Life and Environmental Science, Nishikawatsu,690-8504, Matsue, Japan; nkobayashi@life.shimane-u.ac.jp \\ ${ }^{3}$ Niigata Prefectural Botanical Garden, 186 Kanazu, Niigata, Japan; ykurashige@greenery-niigata.or.jp
}

\begin{abstract}
Evergreen azaleas grow in acid soil and suffer from iron deficiency when cultivated in substrate with pH higher than 6.0. In order to select tolerant plants, 11 azalea genotypes were tested for 21 days in alkaline solution ( $\mathrm{pH} 9$ ), buffered with sodium hydrogen carbonate $\left(1 \mathrm{~g} \cdot \mathrm{l}^{-1}\right)$. Leaf damage, root length and mortality rate were recorded. While leaf damage and mortality rate allowed to discriminate genotypes, root development appeared not directly linked to iron deficiency tolerance. Rhododendron 'Juko', $R$. scabrum, $R$. macrosepalum 'Hanaguruma', $R$. x pulchrum 'Oomurasaki', and $R$. x pulchrum 'Sen-e-oomurasaki' resulted iron efficient genetic resources, useful for azalea cultivation and gardening in calcareous soils. On the contrary, $R$. obtusum 'Kirin', $R$. tosaense, $R$. x mucronatum 'Fujimanyo' and $R$. obtusum 'Susogo-no-ito' resulted iron deficiency sensitive genotypes. $R$. x mucronatum 'Ryukyushibori' and $R$. indicum 'Kinsai' showed intermediate responses.
\end{abstract}

Keywords: alkalinity, breeding, iron chlorosis, Rhododendron, sodium hydrogen carbonate

\section{Introduction}

Evergreen azaleas (family Ericaceae, genus Rhododendron, subgenus Tsutsusi) originate from Southeast Asia and grow principally in Japan on land that is mostly covered by Brown forest soil (53\%) and Andosols (17\%) (Kanno et al., 2008). The lack of limestone found there is suitable for azaleas, whose development is optimized in soils with $\mathrm{pH}$ of 4.5 to 6.0 and relatively low $\mathrm{Ca}, \mathrm{Mg}$, and $\mathrm{K}$ nutrient content (Kofranek and Lunt, 1975; Galle, 1987). Conversely, iron unavailability induced by alkaline soils $(\mathrm{pH} \geq 6.0$ or above) leads to iron deficiency symptoms: interveinal chlorosis in newly-formed leaves, shoot and root growth reduction, leaf wilting, defoliation, and finally, plant death (Rombolà and Tagliavini, 2007). Plant iron deficiency is a global problem, particularly in calcareous soils. It limits not only the production levels of various field crops (Marschner, 1995; Hansen et al., 2007), but also cultivation of the popular ornamental azalea plant (Kofranek and Lunt, 1975; Wallace and Wallace, 1986; Chaanin and Preil, 1994; Preil and Ebbinghaus, 1994; AIPH and Union Fleur, 2013).

Using cultivars or rootstocks highly tolerant to iron deficiency stress is an approach that allows strong results control. This strategy has been widely adopted for herbaceous crops and fruit trees (Alcántara et al., 2012). Preil and Ebbinghaus (1994) proposed the use of the lime-tolerant
Rhododendron 'Cunningham's White' as rootstock based on in vitro and field screenings. In azalea, putative-tolerant genotypes have been observed in Japanese wild habitats with alkaline soil (pH up to 8.0), but few data are available (Scariot and Kobayashi, 2008). While iron deficiency-tolerant genotypes are commonly selected by growing plants in calcareous soils, field tests often suffer from soil heterogeneity and variable environmental conditions (Jessen et al., 1986). To control plant growth conditions, one alternative is to use a homogeneous substrate capable of inducing iron chlorosis (Alcántara et al., 2012), such as hydroponics with sodium hydrogen carbonate $\left(\mathrm{NaHCO}_{3}\right)$ as the medium buffer. This process to screen for iron-efficient plants has been well documented (Chaney et al., 1992), and was employed in this study to screen 11 evergreen azaleas of wide-ranging morphological and ornamental characteristics to select iron efficient genotypes.

\section{Materials and methods}

Two species and nine cultivars of evergreen azaleas were selected based on their wide-ranging morphological and ornamental characteristics, and different parentages (Table 1). Plants were clonally multiplied by cuttings in a commercial nursery devoted to the production of acidophilic ornamental plants (Tecnoverde di Cesa s.p.a., Verbania, Piedmont - Italy). During May 2012, eight months old plants 
Table 1. Azalea genotypes selected for the trial, with related parentage, and main flower and plant characteristics

\begin{tabular}{|c|c|c|c|}
\hline Genotype & Parentage & Flowersize & Note \\
\hline R. indicum 'Kinsai' & $R$ indicum $(\mathrm{L}$.) Sweet & Small & $\begin{array}{l}\text { Low to medium shrub, densely branched; separate } \\
\text { narrow petals; reddish orange flowers }\end{array}$ \\
\hline$R$. 'Juko' & R. indicum (L.) Sweet, R eriocarpum (Hayata) Nakai & Large & $\begin{array}{l}\text { Low to medium shrub, spreading densely branched; } \\
\text { light purplish pink to dark pink flowers with white } \\
\text { centre (many variations); late blooming }\end{array}$ \\
\hline R. obtusum 'Kirin' & R. kaempferi Planch, R. kiusianum Makino & Small & $\begin{array}{c}\text { Medium to tall dense shrub; strong pink, hose in hose } \\
\text { flowers }\end{array}$ \\
\hline R. obtusum 'Susogo-no-ito' & R. kaempferi Planch, R. kiusianum Makino & Small & $\begin{array}{l}\text { Medium to tall dense shrub; reddish purple flowers } \\
\text { with darker blotch }\end{array}$ \\
\hline R. macrosepalum 'Hanaguruma' & R. macrosepalum Maxim. & Large & $\begin{array}{l}\text { Low to medium shrub; purplish pink flowers; spider } \\
\text { type }\end{array}$ \\
\hline R.x mucronatum 'Füjmanyo' & R. ripense Makino, R. macrosepalum Maxim. & Large & $\begin{array}{c}\text { Broad, medium to largeshrub; double form, reddish } \\
\text { purple flowers }\end{array}$ \\
\hline R. x mucronatum 'Ryukyushibori' & R. ripense Makino, $R$. macrosepalum Maxim. & Large & $\begin{array}{c}\text { Broad, medium to largeshrub; vivid purplish red } \\
\text { flowers }\end{array}$ \\
\hline R.xpulchrum 'Oomurasaki' & $\begin{array}{c}\text { R. ripense Makino, R. macrosepalum Maxim., R.scabrum } \\
\text { G.Don }\end{array}$ & Large & $\begin{array}{c}\text { Vigorous and hardy shrub; deep purplish red flowers } \\
\text { with darker blotch }\end{array}$ \\
\hline R.xpuldhrum 'Sen-e-oomurasaki' & $\begin{array}{c}\text { R. ripense Makino, R. macrosepalum Maxim., R. scabrum } \\
\text { G.Don }\end{array}$ & Large & Double flower sports of $R$ x pulchrum 'Oomurasaki' \\
\hline R. scabrum G.Don & & Large & $\begin{array}{l}\text { Large vigorous shrub; reddish orange to rosy purple } \\
\text { flowers with darker blotch }\end{array}$ \\
\hline R. tosaense Makino & & Small & Low shrub; purplish red flowers \\
\hline
\end{tabular}

were hydroponically cultivated with two different nutrient solutions for 21 days. Single plant was placed in $100 \mathrm{~mL}$ plastic pot and 10 plants per treatment were used for each genotype. The control nutrient solution of moderate acid reaction $(\mathrm{pH}=6)$ was prepared with deionized water and $0.5 \mathrm{gLL}^{-1}$ of water soluble fertilizer, containing $20 \% \mathrm{~N}, 20 \% \mathrm{P}, 20 \% \mathrm{~K}, 0.02 \% \mathrm{~B}, 0.01 \%$ Mo, $0.7 \% \mathrm{Mg}, 1.5 \% \mathrm{~S}, 0.015 \% \mathrm{Cu}-\mathrm{EDTA}, 0.12 \%$ Fe-DTPA, $0.06 \% \mathrm{Mn}$-EDTA and $0.015 \% \mathrm{Zn}$-EDTA (Peters Professional', Scotts Company LLC, Dublin, OH, USA). A strong alkaline solution $(\mathrm{pH}=9)$ was made by the addition of $1 \mathrm{gt}^{-1}$ of $\mathrm{NaHCO}_{3}$ to the control solution. The nutrient solutions were renewed every week to sustain a constant $\mathrm{pH}$ level. Cultures were maintained in a growth chamber at $20^{\circ} \mathrm{C}, 60 \%$ relative humidity and $16 \mathrm{~h}$ photoperiod, with a photosynthetically active radiation (PAR) of $157 \mu \mathrm{mol} \cdot \mathrm{m}^{-2} \cdot \mathrm{s}^{-1}$ at the top of the canopy, provided by high pressure sodium lamps. On the first day of the trial and every seven days thereafter, plant height and root length were measured. At the same time, the plants were inspected for chlorotic, browned, or wilted leaves. Based on the recorded data, leaf damage was assessed and a score was assigned based on a rating scale between 0 to 4 , in which $0=$ no damage, $1=1-25 \%$ leaf damage, $2=26-50 \%$ leaf damage, $3=51-75 \%$ leaf damage, and 4 > 75\% leaf damage (Cassaniti et al., 2009; Caser et al.,2013). After 21 days of cultivation, the mortality rate and the plant height and root length variations were calculated.

All measured and derived data were firstly subjected to the homogeneity of the variances and then means were evaluated by the analysis of variance (one-way ANOVA) using Ryan-EinotGabriel-Welsch's multiple step-down F (REGW-F) post-hoc test $(P \leq 0.05)$. All analyses were performed with SPSS Statistics Software 21.0 (IBM Co., Armonk, NY, USA). Principal Component Analysis (PCA) was performed on root length variation, leaf damage, and mortality rate recorded after 21 days under the alkaline stress condition. The first two axes were plotted according to the extracted Eigen vectors, using the software package NTSYS-pc version 2.1 (Applied Biostatistics Inc., Port Jefferson, NY, USA).

\section{Results and discussion}

Iron deficiency symptoms are largely known to include interveinal chlorosis in apical leaves, reduction of shoot and root growth, leaf wilting and abscission, and finally, plant death (Rombolà and Tagliavini, 2007). In this study, defoliation was not estimated given the diverse plant behaviours associated with the various genotypes. Indeed, new leaf formation is strictly genotypedependent, with different timings and patterns. Moreover, some evergreen azalea species ( $R$ x pulchrum) damaged leaves fall versus others ( $R$ obtusum 'Kirin') that wilt on the shoots without falling. Due to the slow nature of azalea development, plant height of all 11 genotypes did not significantly increased during the experiment (data not shown). Similarly, at day seven and 14 no differences were highlighted in leaf damage and root elongation.

On the other hand, leaf damage, root length variation, and mortality rate differed among the 11 azaleas after 21 days of cultivation, both in $\mathrm{pH}=6$ and $\mathrm{pH}=9$ solutions (Table 2). In all genotypes, alkaline $\mathrm{pH}$ negatively influenced at least one of these parameters compared to the control $(\mathrm{pH}=6)$, except for $R \times \mathrm{x}$ pulchrum 'Oomurasaki' that showed slight leaf damage, root elongation, and low mortality indiscriminately. At $\mathrm{pH}=9$, slight leaf damages - similar to the control - were observed in $R$. 'Juko', $R$. scabrum, $R$ x mucronatum 'Ryukyushibori', $R$ macrosepalum 'Hanaguruma', as well as in the two $R$ x pulchrum cultivars. These same genotypes exhibited low mortality rates. $R$. scabrum had the lowest leaf damage (0.9) and no mortality (0\%). In contrast, we observed severe leaf iron deficiency symptoms in $R$. obtusum 'Kirin', $R$ tosaense, and $R$. mucronatum 'Fujimanyo' (leaf damage $=4.0$ ). These azaleas also showed high mortality rates $(80 \%, 100 \%$, and $100 \%$ respectively), as did $R$ obtusum 'Susogo-no-ito' (90\%). Root elongation was affected by alkaline $\mathrm{pH}$ in three genotypes. Compared to control $(\mathrm{pH}=6)$, root growth was inhibited in $R$. obtusum 'Susogo-no-ito' and R. scabrum, while was enhanced in $R . \mathrm{x}$ mucronatum 'Fujimanyo'. 
212

Table 2. Effects of acid and alkaline nutrient solutions on leaf damage, root elongation ( $\Delta=$ root length at day $21-$ root length at day 0$)$ and mortality rate after 21 days of cultivation on the 11 studied azalea genotypes

\begin{tabular}{|c|c|c|c|c|c|c|c|c|}
\hline \multirow[t]{2}{*}{ Genotype } & \multicolumn{3}{|c|}{$\begin{array}{l}\text { Leaf damage } \\
\text { (classes) }^{z}\end{array}$} & \multicolumn{3}{|c|}{$\begin{array}{c}\Delta \text { Root length } \\
(\mathrm{cm})\end{array}$} & \multicolumn{2}{|c|}{$\begin{array}{c}\text { Mortality } \\
(\%)\end{array}$} \\
\hline & $\mathrm{pH} 6$ & $\mathrm{pH} 9$ & $P$ & $\mathrm{pH} 6$ & $\mathrm{pH} 9$ & $P$ & $\mathrm{pH} 6$ & $\mathrm{pH} 9$ \\
\hline R. indicum 'Kinsai' & $0.00 c^{y}$ & $3.3 \mathrm{abcd}$ & *** & $-0.20 c$ & $0.2 \mathrm{ab}$ & NS & 0 & 50 \\
\hline$R$. 'Juko' & $0.70 \mathrm{bc}$ & $2.0 \mathrm{def}$ & NS & $0.35 \mathrm{abc}$ & $0.3 \mathrm{ab}$ & NS & 0 & 30 \\
\hline R. obtusum 'Kirin' & $1.20 \mathrm{bc}$ & $4.0 \mathrm{ab}$ & $* * *$ & $-1.80 \mathrm{~d}$ & $-1.2 c$ & NS & 0 & 80 \\
\hline R. macrosepalum 'Hanaguruma' & $1.50 \mathrm{bc}$ & 2.8 abcde & * & $0.55 \mathrm{abc}$ & $0.5 \mathrm{ab}$ & NS & 20 & 30 \\
\hline R. x mucronatum 'Fujimanyo' & $2.30 \mathrm{abc}$ & $4.0 \mathrm{ab}$ & $*$ & $0.15 \mathrm{bc}$ & $1.0 \mathrm{a}$ & $*$ & 50 & 100 \\
\hline R. x mucronatum 'Ryukyushibori' & $1.30 \mathrm{bc}$ & 2.5 bcdef & NS & $0.30 \mathrm{abc}$ & $0.2 \mathrm{ab}$ & NS & 10 & 50 \\
\hline R. x pulchrum 'Oomurasaki' & $1.20 \mathrm{bc}$ & $2.0 \mathrm{cdef}$ & NS & $0.95 \mathrm{abc}$ & $0.2 \mathrm{ab}$ & NS & 10 & 20 \\
\hline R. x pulchrum 'Sen-e-oomurasaki' & $0.80 \mathrm{bc}$ & $1.4 \mathrm{ef}$ & NS & $0.60 \mathrm{abc}$ & $-0.5 b c$ & NS & 0 & 20 \\
\hline R. scabrum & $1.10 \mathrm{bc}$ & $0.9 \mathrm{f}$ & NS & $0.75 \mathrm{abc}$ & $-0.3 a b c$ & *** & 0 & 0 \\
\hline R. obtusum 'Susogo-no-ito' & $1.40 \mathrm{bc}$ & $3.6 \mathrm{abc}$ & ** & $1.40 \mathrm{a}$ & $0.0 \mathrm{ab}$ & $* * *$ & 10 & 90 \\
\hline R. tosaense & $2.60 \mathrm{ab}$ & $4.0 \mathrm{ab}$ & $*$ & $0.00 \mathrm{c}$ & $0.1 \mathrm{ab}$ & NS & 60 & 100 \\
\hline$P$ & $*$ & ** & & $* *$ & $* *$ & & & \\
\hline
\end{tabular}
according to REGWF post-hoc test. Mean effect within line are reported. NS, , ,**** Non significant or significant at $p=0.05,0.01$, and 0.001 , respectively.

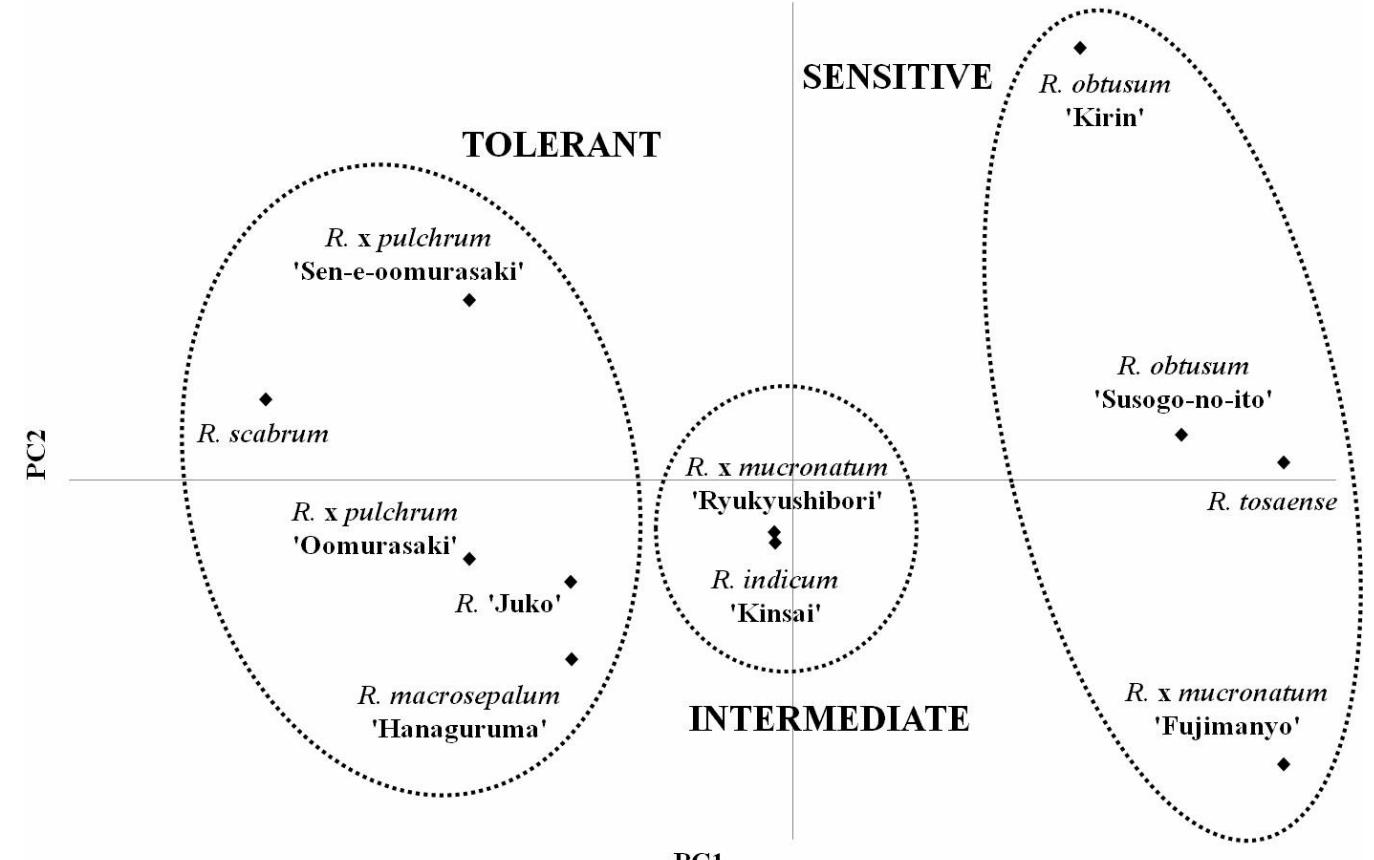

PC1

Fig. 1. Scatter diagram of 11 azalea genotypes obtained performing the Principal Component Analysis (PCA) on iron deficiency response parameters (leaf damage, mortality rate and variation of root length) recorded after 21 days of cultivation in solution at $\mathrm{pH} 9$. The first two components explain $99.96 \%$ and $0.03 \%$ of the total variation

Principal Component Analysis (PCA) allowed better classification of the 11 azalea genotypes according to their iron deficiency tolerance (Fig. 1), as the first two components accounted for $99.96 \%$ and $0.03 \%$ of variation. The attributes responsible for separation were (with values in parentheses) leaf damage (4.4 e-04) and mortality (4.0 e-04) along the first component (PC1), and root length (0.759) and mortality (0.654 ) along the second (PC2). This result allowed the genotypes to be sorted into three distinct groups: $R$. 'Juko', $R$. macrosepalum 'Hanaguruma', $R$. scabrum, and the two $R . x$ pulchrum cultivars resulted as tolerant to iron deficiency; $R . \mathrm{x}$ mucronatum 'Fujimanyo', $R$. obtusum 'Susogo-no-ito', $R$. tosaense, and $R$. obtusum 'Kirin' resulted as sensitive; $R . \mathrm{x}$ mucronatum 'Ryukyushibori' and $R$. indicum 'Kinsai' showed intermediate responses to alkaline $\mathrm{pH}$ condition. A similar gradation in iron shortage responses among plants is usually observed when a large number of genotypes is tested (Preil and Ebbinghaus, 1994; Alcántara et al., 2012). Iron deficiency responses appeared to relate closely to parentages and natural environment adaptation differences (Scariot et al., 2007). Most likely, the wild species $R$. macrosepalum, $R$ scabrum, and $R$. ripense (series Scabra) and $R$ e eriocarpum (series Tsutsusi) are iron deficiency-tolerant. These species normally grow along forest edges, at the seaside, or on stony river areas where they could have developed tolerance to different abiotic stresses (Scariot and Kobayashi, 2008), whereas R. kaempferi and R. kiusianum (series Kaempferia), and $R$. tosaense (series Tsutsusi) that grow on acidic volcanic soil (Scariot and Kobayashi, 2008) are iron deficiencysensitive. 
Plant root systems perform many essential adaptive functions and structural changes can deeply affect the nutrients absorption capacity of plants. Under iron deficiency conditions, root elongation usually increases. However, some studies report that alkaline $\mathrm{pH}$ inhibits root growth both in tolerant and sensitive plants, while others describe unaffected root elongation, even among sensitive genotypes (Chaanin and Preil, 1994; Preil and Ebbinghaus, 1994; Alcántara et al., 2000; Valdez-Aguilar and Reed, 2006; Wulandari et al., 2014). The tolerance to alkalinity we observed in iron-efficient evergreen azaleas seems not related to root system development, but other physiological factors could be involved, such as enhanced proton extrusion (Wulandari et al., 2014), ethylene or auxin synthesis (Schmidt et al., 2000), or iron chelate reductase activity of the roots (Bienfait, 1988).

\section{Conclusions}

The present trial represents the first attempt to discriminate evergreen azaleas tolerant to iron deficiency that would allow selection of five putative iron-efficient genotypes ( $R$. 'Juko', $R$. macrosepalum 'Hanaguruma', $R$. scabrum, $R$. $x$ pulchrum 'Oomurasaki' and $R$. x pulchrum 'Sen-e-oomurasaki'). These plants might be used for cultivation and gardening in calcareous soils, or as breeding materials for iron deficiency tolerance breeding. Nevertheless, further experimentation on commonly used substrates is necessary to test azalea responses under authentic cultivation practices. Furthermore, investigation to unravel the mechanism beyond iron deficiency tolerance of this acidophilic plant could improve selection protocols.

\section{Acknowledgments}

The research was financially supported by the Italian "Ministero dell'Istruzione, dell'Università e della Ricerca" (project PRIN 2009, prot. 2009BW3KL4_003).

\section{References}

AIPH (International Association of Horticultural Producers), Union Fleur (2013). International Statistics - Flowers and Plants 2013. Vol. 61. Zentrum für Betriebswirtschaft im Gartenbau e.V. an der Leibniz Universität Hannover.

Alcántara E, Romera FJ, Cañete M, De la Guardia MD (2000). Effects of bicarbonate and iron supply on $\mathrm{Fe}(\mathrm{III})$ reducing capacity of roots and leaf chlorosis of the susceptible peach rootstock 'Nemaguard'. J Plant Nutr 23:1607-1617.

Alcántara E, Montilla I, Ramírez P, García-Molina P, Romera FJ (2012). Evaluation of quince clones for tolerance to iron chlorosis on calcareous soil under field conditions. Sci Hortic 138:50-54.

Bienfait HF (1988). Mechanisms in Fe-efficiency reactions of higher plants. J Plant Nutr 11:605-629.

Caser M, Scariot V, Gaino W, Larcher F, Devecchi M (2013). The effects of sodium chloride on the aesthetic value of Buxus spp. Eur J Hortic Sci 78:153-159.

Cassaniti C, Leonardi C, Flowers TJ (2009). The effect of sodium chloride on ornamental shrubs. Sci Hortic 122:586-593.
Chaanin A, Preil W (1994). Influence of bicarbonate on iron deficiency chlorosis in Rhododendron. Acta Hort 364:71-78.

Chaney RL, Coulumbe BA, Bell PF, Angle SJ (1992). Detailed method to screen dicot cultivars for resistance to Fe-chlorosis using FeDTPA and bicarbonate in nutrient solutions. J Plant Nutr 15:1857-1875.

Galle FC (1987). Azaleas. Timber Press, Portland, 486 p.

Hansen NC, Hopkins BG, Ellsworth JW, Jolley VD (2007). Iron nutrition in field crops, p. 23-59. In: Barton LL, Abadía J (Eds.). Iron nutrition in plants and rhizospheric microorganisms. Springer, Dordrecht.

Jessen HJ, Fehr WR, Piper TE (1986). Alternatives to conventional field evaluation for genetic selection for Fe-efficiency of soybean. J Plant Nutr 9:345-353.

Kanno H, Hirai H, Takahashi T, Nanzyo M (2008). Soil regions map of Japan based on a reclassification of the 1:1 million soil map of Japan (1990) according to the Unified Soil Classification System of Japan $-2^{\text {nd }}$ approximation (2002). Pedologist 52:129-133 (in Japanese).

Kofranek AM, Lunt OR (1975). Mineral nutrition, p. 36-46. In: Kofranek AM, Larson RA (Eds.). Growing azaleas commercially. Division of Agricultural Sciences, University of California, Davis, California.

Marschner H (1995). Mineral nutrition of higher plants (2 $\left.2^{\text {nd }} E d\right)$. Academic Press, Cambridge, 889 p.

Preil W, Ebbinghaus R (1994). Breeding of lime tolerant Rhododendron rootstocks. Acta Hort 364:61-70.

Rombolà $\mathrm{AD}$, Tagliavini $\mathrm{M}$ (2007). Iron nutrition of fruit tree crops, $\mathrm{p}$. 61-83. In: Barton LL, Abadía J (Eds.). Iron nutrition in plants and rhizospheric microorganisms. Springer, Dordrecht.

Scariot V, Handa T, De Riek J (2007). A contribution to the classification of evergreen azalea cultivars located in the Lake Maggiore area (Italy) by means of AFLP markers. Euphytica 158:47-66.

Scariot V, Kobayashi N (2008). Evaluation of variability in Japanese wild azaleas and application of lime-tolerant genetic resources for breeding. In: Book of Abstract of the First Symposium on Horticulture in Europe, February 17-20, Vienna 2008, 268-269.

Schmidt W, Tittel J, Schikora A (2000). Role of hormones in the induction of iron deficiency responses in Arabidopsis roots. Plant Physiol 122:1109-1118.

Valdez-Aguilar LA, Reed DW (2006). Comparison of growth and alkalinity-induced responses in two cultivars of hibiscus (Hibiscus rosa-sinensis L.). HortScience 41:1704-1708.

Wallace A, Wallace GA (1986). Ornamental plants most likely to be killed by iron deficiency and some control measures. J Plant Nutr 9:1009-1014.

Wulandari C, Muraki S, Hisamura A, Ono H, Honda K, Kashima T, Subandiyah S, Masaoka Y (2014). Effect of iron deficiency on root ferric chelate reductase, proton extrusion, biomass production and mineral absorption of citrus root stock Orange Jasmine (Murraya exotica L.).J Plant Nutr 37:50-64. 